\title{
Trichomonal vaginitis refractory to treatment: case report
}

\author{
M S SPROTT, * ANGELA M KEARNS,* R S PATTMAN $\dagger$ \\ From the * Regional Public Health Laboratory, Institute of Pathology, and the $\dagger$ Department of Genitourinary \\ Medicine, General Hospital, Newcastle upon Tyne
}

SUMMARY A woman initially aged 25 was treated for seven years for symptomatic vaginal trichomoniasis. Throughout that period the patient received 5-nitroimidazoles at conventional and high dosages, antimicrobial agents to eliminate vaginal organisms capable of interfering with treatment, acidifying preparations, and vaccination with inactivated Lactobacillus acidophilus. Despite all the regimens used, the condition remained refractory to treatment.

\section{Case report}

A woman aged 28 attended the department of genitourinary medicine in October 1984. She had been referred by her general practitioner who, for the previous three years, had been treating her unsuccessfully for a recurrent offensive vaginal discharge (details of the drug regimen prescribed are not available). At her first visit to the clinic, Trichomonas vaginalis was found in a wet preparation of vaginal secretions, and metronidazole $200 \mathrm{mg}$ three times a day for one week was prescribed.

During the next six months she had recurrent symptomatic trichomoniasis, which was found to coincide with menstruation. Varying treatment regimens were used, including oral metronidazole ranging from $600 \mathrm{mg}$ to $1.2 \mathrm{~g}$ a day, nimorazole $2 \mathrm{~g}$ as a single oral dose, and metronidazole $1 \mathrm{~g}$ suppositories used daily as pessaries. On three occasions erythromycin, doxycycline, or septrin was given concurrently, as it has been suggested that concomitant bacteria may inactivate metronidazole..$^{1-3}$ These agents were used because the patient stated that she was allergic to penicillin. In addition, acidifying preparations, such as acetic acid vaginal jelly and povidone-iodine pessaries, were used during menstruation. She had had only one sexual partner during the previous eight years, and he was also given concurrent epidemiological treatment on three separate occasions. Sexual activities were stated to

\footnotetext{
Address for reprints: Dr M S Sprott, Department of Microbiology, Institute of Pathology, Newcastle General Hospital, Westgate Road, Newcastle upon Tyne NE4 6BE
}

Accepted for publication 1 July 1988
Table 1 Minimum inhibitory concentrations (MICs) of metronidazole for isolates of Trichomonas vaginalis

\begin{tabular}{|c|c|c|c|c|}
\hline \multirow[b]{2}{*}{$\begin{array}{l}\text { Isolate } \\
\text { No }\end{array}$} & \multirow[b]{2}{*}{$\begin{array}{l}\text { Times } \\
\text { assayed }\end{array}$} & \multirow[b]{2}{*}{$\begin{array}{l}\text { Date } \\
\text { assayed }\end{array}$} & \multicolumn{2}{|c|}{$M I C s$ (mg/l) under: } \\
\hline & & & $\begin{array}{l}\text { Aerobic } \\
\text { conditions }\end{array}$ & $\begin{array}{l}\text { Anaerobic } \\
\text { conditions }\end{array}$ \\
\hline $\begin{array}{l}32462 \\
47335 \\
32966 \dagger \\
44578 \dagger \\
118216\end{array}$ & $\begin{array}{l}1 \\
1 \\
3 \\
2 \\
1\end{array}$ & $\begin{array}{l}\text { April } 1985 \\
\text { June } 1985 \\
\text { April } 1986 \\
\text { June } 1986 \\
\text { Jan } 1988\end{array}$ & $\begin{array}{r}2 \\
2 \\
32 \\
32 \\
64\end{array}$ & $\begin{array}{l}1 \\
2 \\
2 \\
2 \\
2\end{array}$ \\
\hline
\end{tabular}

* Reference strains were included with each assay.

† MIC of nimorazole: $32 \mathrm{mg} / \mathrm{l}$ aerobically, $4 \mathrm{mg} / \mathrm{l}$ anaerobically.

have been discontinued for at least a month during medication.

As the infection persisted, further investigations were carried out. A full gynaecological examination showed no abnormality. High vaginal secretions were cultured for the presence of organisms that possibly inactivate metronidazole (Escherichia coli, Streptococcus milleri, and Bacteroides fragilis were isolated). Serum zinc concentrations were measured and found to be within normal limits at $14.0 \mu \mathrm{mol} / 1 .{ }^{45}$ Using the method described by Nielsen, ${ }^{6}$ the minimum inhibitory concentrations (MICs) of metronidazole for $T$ vaginalis isolated on two occasions two months apart were examined and found to be $2 \mathrm{mg} / \mathrm{l}$ under aerobic conditions (table 1). As the organism was not resistant to metronidazole, investigations were undertaken to exclude inadequate absorption of this agent. Serum and vaginal concentrations one hour after the patient had received $800 \mathrm{mg}$ by mouth were assayed microbiologically by a plate diffusion method,' and were found to be satisfactory (table 2). 
Table 2 Serum and vaginal concentrations of metronidazole one hour after administration of $800 \mathrm{mg}$ by mouth twice a day

\begin{tabular}{lll}
\hline & \multicolumn{2}{l}{ Concentration $(\mathrm{mg} / \mathrm{l})$ in: } \\
\cline { 2 - 3 } Day of treatment & Serum & Vaginal secretions \\
\hline 1 & $30 \cdot 1$ & $15 \cdot 0$ \\
2 & $22 \cdot 0$ & $14 \cdot 0$ \\
3 & $29 \cdot 0$ & $14 \cdot 0$ \\
\hline
\end{tabular}

The patient was referred for examination of her immunological status. Concentrations of immunoglobulin (Ig), including IgG, IgA, and IgM, were assayed; responses to phytohaemagglutinin, purified protein derivative (PPD), and candida were assessed; and the in vitro lymphocyte responses against PPD and trichomonal extract were measured. The results of these studies showed no evidence of a T cell deficiency against $T$ vaginalis or of a more generalised state of immune deficiency. In view of this we undertook immunisation with inactivated Lactobacillus acidophilus. The vaccine was given in three intramuscular injections of $0.5 \mathrm{ml}$ each at intervals of two weeks. Concurrent with the first vaccination, the patient was prescribed $400 \mathrm{mg}$ metronidazole twice a day for seven days. After the first injection she complained of feeling unwell and feverish and had a sore buttock. She experienced no side effects to subsequent injections.

She was reviewed in April 1986, one month after she had completed her course of vaccinations, and was again found to have $T$ vaginalis in vaginal secretions. The MIC of metronidazole for this isolate was $32 \mathrm{mg} / \mathrm{l}$ under aerobic conditions (table 1). At follow up five weeks later she continued to harbour $T$ vaginalis, which was also inhibited by $32 \mathrm{mg} / \mathrm{l}$. On this occasion, nimorazole $1 \mathrm{~g}$ twice a day for three doses was prescribed, but without effect. The MIC of nimorazole for $T$ vaginalis was subsequently shown to be $32 \mathrm{mg} / 1$.

In November or December 1986 the patient conceived. Throughout her pregnancy she remained totally symptomless. After delivery of the baby trichomoniasis recurred, and she was treated with a seven day course of $400 \mathrm{mg}$ metronidazole three times a day and amoxycillin $250 \mathrm{mg}$ three times a day. The latter was prescribed because, although she had given a history of allergy to penicillin, tablets combining amoxycillin and clavulanic acid had been prescribed post partum with no ill effects. As before, her condition failed to respond to treatment. Repeat investigation of her immunological status confirmed that there was no deficiency in cellular, humoral, or mucosal immunity, and a further study of $T$ vaginalis isolated in January 1988 showed an MIC of metronidazole of $64 \mathrm{mg} / \mathrm{l}$ under aerobic conditions. Symptomatic and apparent temporary clinical improvement has since been achieved by administer- ing metronidazole suppositories $1 \mathrm{~g}$ a day for seven days as pessaries, as required.

\section{Discussion}

The recognition of the activity of the 5-nitroimidazoles against anaerobic protozoa has led to their use in treating patients with trichomonal infection. ${ }^{89}$ The most commonly prescribed agent is metronidazole, either as a standard dose for up to seven days or a high dose for a short term. Cure rates vary from $82-95 \%$, according to the dose and regimen used. ${ }^{10-16}$

Failure of trichomonal infection to respond to conventional treatment is rare,,$^{4517-22}$ and the theories that have been advanced to account for treatment failure include: inadequate drug concentrations, inactivation of metronidazole by bacteria, low serum zinc concentrations, immunological defect, resistance to metronidazole, and reinfection.

Kane et al suggested inadequate drug concentrations because of either poor patient compliance or malabsorption. ${ }^{23}$ Our patient, however, appeared to be co-operative, and serum and vaginal concentrations assayed while she was in hospital proved to be satisfactory.

Several workers have reported that some organisms absorb and inactivate metronidazole, ${ }^{1-3}$ and treatment failure may be attributed to this phenomenon. To overcome this we prescribed for our patient high dose metronidazole combined with broad range antimicrobial agents, but they proved to be ineffective.

Reports implicating low zinc concentrations in body fluids as a cause of treatment failure ${ }^{524}$ led us to assay serum zinc concentrations in our patient, but they were found to be within normal limits.

Abnormalities of hosts may account for failure to respond to treatment. Immunological studies of our patient showed no evidence of a generalised immunodeficiency state or of $\mathrm{T}$ cell immune deficiency against the trichomonal isolate. In view of the normal immune response, we decided to undertake immunisation with a lyophilisate of inactivated selected strains of $L$ acidophilus. The mode of action is not certain, but the vaccine may induce cross reacting antibodies against $T$ vaginalis and abnormal lactobacilli without adversely affecting the growth of normal lactobacilli in the vagina. Lorenz and Ruttgers reported that after the third vaccination no trichomonads could be found in $84 \%$ of women, and after one year this figure had risen to $96 \%{ }^{25}$ Reinfection after completion of the course and a booster vaccination occurred in only $4-5 \%$ of cases. Unfortunately the vaccine did not prove successful in our patient; $T$ vaginalis was seen in wet preparations during the vaccination schedule and four and nine weeks afterwards.

Recalcitrant trichomonal vaginitis may be caused 
by infection with a trichomonad resistant to metronidazole. The original isolates appeared to be sensitive, with MICs of $2 \mathrm{mg} / 1$ under aerobic conditions. The MICs for organisms isolated after one year, however, were 32-64 mg/l. This difference could have resulted from technical error, but table 1 shows that assays performed on organisms isolated on more than one occasion gave similar results. Increasing MICs for successive isolates may reflect resistance induced by repeated courses of 5-nitroimidazoles. Although Kulda et al could show no increase in resistance to metronidazole in a strain of $T$ vaginalis that was isolated repeatedly from a patient who had had several courses of treatment, ${ }^{18}$ De Carneri et al observed that by passaging $T$ vaginalis in media containing increasing concentrations of metronidazole the minimum trichomonicidal concentration of metronidazole rose from $0.23 \mathrm{mg} / 1$ to $80 \mathrm{mg} / \mathrm{l}^{26}$ They were also able to increase in vivo resistance in mice by up to 14.5 times. ${ }^{272}$ Forsgren and Forssman speculated that suboptimal doses of metronidazole in vaginal secretions may induce resistance to imidazole. ${ }^{17}$

The difference in sensitivity of isolates could be attributed to reinfection. Our patient appeared to be reliable and said that she had had only one regular sexual partner for many years, and her consort said that he had had no other sexual contacts. Although it is unlikely, however, another sexual partner cannot be categorically discounted.

In this patient, symptomatic trichomoniasis invariably started at the onset of menstruation, and she remained asymptomatic throughout her pregnancy. The $\mathrm{pH}$ of the vagina decreases from a mean of 6.6 in week one of the menstrual cycle to 4.3 in week four, ${ }^{29}$ and in pregnancy varies from 3.8-4.4. ${ }^{30}$ This acid environment may prove unsuitable for $T$ vaginalis, as the organism appears to prefer a pH of 5-8..$^{31}$ After the satisfactory completion of her pregnancy the patient was again found to harbour $T$ vaginalis (with an MIC of $64 \mathrm{mg} / \mathrm{l})$. This could be attributed to reinfection, but $T$ vaginalis may have persisted in some other genitourinary or gastrointestinal site and been able to re-establish infection when the vaginal $\mathrm{pH}$ returned to normal after parturition.

In this report we present the history of a patient with recalcitrant trichomoniasis that failed to respond to all forms of treatment. There is clearly a need for alternative antitrichomonal treatment. Sears and O'Hare assessed the susceptibility of a metronidazole resistant strain of $T$ vaginalis to a range of antimicrobial agents, and found that mebendazole, furazolidone, and anisonmycin were the most active. ${ }^{32}$ Whether these in vitro findings offer an alternative successful approach in the clinical situation needs further study.
We thank Dr A G Bird of the immunology department, Newcastle General Hospital, and the staff of Preston Hospital, North Tyneside, for their help in investigating this patient, and Mrs C Laidlow for typing the manuscript.

\section{References}

1 Edwards DI, Thompson EJ, Tomusange J. Inactivation of metronidazole by aerobic organisms. J Antimicrob Chemother 1979;5:315-6.

2 Nicol CS, Evans AJ, McFadzean JA, Squires SL. Inactivation of metronidazole. Lancet 1966;ii:441.

3 Ralph ED, Clarke DA. Inactivation of metronidazole by anaerobic and aerobic bacteria. Antimicrob Agents Chemother 1978;14:377-83.

4 Ahmed-Jushuf IH, Murray AE, McKeown J. Managing trichomonal vaginitis refractory to conventional treatment with metronidazole. Genitourin Med 1988;64:25-9.

5 Willmott F, Say J, Downey D, Hookham A. Zinc and recalcitrant trichomoniasis. Lancet 1983; ; 1053.

6 Nielsen R. Trichomonas vaginalis. II. Laboratory investigations in trichomoniasis. British Journal of Venereal Diseases 1973;49:531-5.

7 Waterworth P. Laboratory control. In: Garrod LP, Lambert HP, O'Grady F, eds. Antibiotic and chemotherapy. 5th ed. Edinburgh: Churchill Livingstone, 1981:464-504.

8 Cosar C, Julou L. Activité de l'(hydroxy-2'éthyl)-1 méthyl-2 nitro5 imidazole (8.823 R.P) vis-à-vis des infections expérimentales à Trichomonas vaginalis. Annales de L'Institut Pasteur (Paris) 1959;96:238-41.

9 Sköld M, Gnarpe H, Hillström L. Ornidazole: a new antiprotozoal compound for treatment of Trichomonas vaginalis infection. British Journal of Venereal Diseases 1977;53:44-8.

10 Csonka GW. Long term aspect of treatment with metronidazole (Flagyl) in trichomonal vaginitis. British Journal of Venereal Diseases 1963;39:258-60.

11 Hager WD, Brown ST, Kraus SJ, Kleris GS, Perkins GJ, Henderson M. Metronidazole for vaginal trichomoniasis. JAMA 1980;244:1219-21.

12 Underhill RA, Peck JE. Causes of therapeutic failure after treatment of trichomonal vaginitis with metronidazole: comparison of single-dose treatment with standard regimen. Br J Clin Pract 1974;28:134-6.

13 Csonka GW. Trichomonal vaginitis treated with one dose of metronidazole. British Journal of Venereal Diseases 1971;47:456-8.

14 Rein MF. Current therapy of vulvovaginitis. Sex Transm Dis 1981;8:316-20.

15 Ross SM. Single and triple dose treatment of Trichomonas infection of the vagina. British Journal of Venereal Diseases 1973;49:475-7.

16 Woodcock KR. Treatment of trichomonal vaginitis with a single oral dose of metronidazole. British Journal of Venereal Diseases 1972;48:65-8.

17 Forsgren A, Forssman L. Metronidazole-resistant Trichomonas vaginalis. British Journal of Venereal Diseases 1979;55:351-3.

18 Kulda J, Vojtechovska M, Tachezy J, Demes P, Kunzova E. Metronidazole resistance of Trichomonas vaginalis as a cause of treatment failure in trichomoniasis. British Journal of Venereal Diseases 1982;58:394-9.

19 Lossick JG, Müller M, Gorrell TE. In vitro drug susceptibility and doses of metronidazole required for cure in cases of refractory trichomoniasis. J Infect Dis 1986;153:948-55.

20 Muller M, Meingassner JG, Miller WA, Ledger WJ. Three metronidazole resistant strains of Trichomonas vaginalis from the United States. Am J Obstet Gynecol 1980;138:808-12.

21 Thurner J, Meingassner JG. Isolation of Trichomonas vaginalis resistant to metronidazole. Lancet 1978;ii:738.

22 Waitkins SA, Thomas DJ. Isolation of Trichomonas vaginalis 
resistant to metronidazole. Lancet 1981;ii:590.

23 Kane PO, McFadzean JA, Squires SL. Absorption and excretion of metronidazole. I. Serum concentration and urinary excretion after oral administration. British Journal of Venereal Diseases 1961;37:273-5.

24 Kreiger JN, Rein MF. Zinc sensitivity of Trichomonas vaginalis: in-vitro studies and clinical implications. $J$ Infect Dis 1982;146:341-5.

25 Lorenz V, Ruttgers H. Clinical experience using SolcoTrichovac in the treatment of Trichomonas infections in women. In: Ruttgers H, ed. Gynakologische Rundschau. Basel: Karger, 1983:23: 64-71.

26 De Carneri I, Achilli G, Monti G, Trane F. Induction of in-vivo resistance of Trichomonas vaginalis to metronidazole. Lancet 1969;ii:1308-9.

27 De Carneri I. Trichomonas vaginalis resistance. Lancet 1966;i:1042-3.

28 De Carneri I, Giannone R. Drug resistance in Trichomonas vaginalis. Lancet 1971 ;i: $1320-1$.

29 Wilks M, Tabaqchali S. Quantitative bacteriology of the vaginal flora during the menstrual cycle. J Med Microbiol 1987; 24:241-5.

30 Trichomonal infestation of the genital tract. In: King A, Nicol C, Rodin P, eds. Venereal diseases. 4th ed. London: Ballière Tindall, 1980:309-19.

31 Cohen MS, Black JR, Proctor RA, Sparling PF. Host defences and the vaginal mucosa. In: Mårdh P-A, Taylor-Robinson D, eds. Bacterial vaginosis. Stockholm: Almqvist and Wiksell, 1984:13-22.

32 Sears SD, O'Hare J. In vitro susceptibility of Trichomonas vaginalis to 50 antimicrobial agents. Antimicrob Agents Chemother 1988;32:144-6. 